\title{
Absorption of Sulphur Onto Organoclay
}

\author{
Habiba Mohammed* \\ Department of Chemical Engineering, Nigeria \\ Submission: October 14, 2018; Published: January 18, 2019 \\ *Corresponding author: Habiba Mohammed, Department of Chemical Engineering, Nigeria
}

Abstract

Due to the abundance of sulphur found in soil under Aerobic condition the main element is being absorbed by the plant and it is brought from three major sources weathered they compose organic matter and atmospheric precipitation. Modified clay is suitable absorbent for the removal of sulphate from contaminated water in terms of natural and commercial absorbent. The maximum sulphate was found to be $119 \mathrm{mg} / \mathrm{L}$ and $13 \mathrm{mg} / \mathrm{L}$ for modified and unmodified clay at $\mathrm{pH}$ of 7.5 in three hours with $580 \mathrm{mg} / \mathrm{L}$ of initial concentration.

\section{Introduction}

Sulphate is the most abundant form of sulfur found in soils under aerobic conditions and the main ionic species of this element that is absorbed by plants. The sulfate interactions with the soil solid phase influence not only its mobility, but also its availability to plants. The study of the reactions and mechanisms of the sulfate-ion adsorption by soils is of great theoretical and practical importance. The adsorption and exchange of anions in soils are significantly less understood than the adsorption and exchange of cations. The practical aspect of this problem is related to the large effect of the soil capacity to adsorb sulfates on the removal of bases from the soil J Environ. Qual. The sorption parameters of soils the buffering properties of soils for acid reagents $\mathrm{RK} \mathrm{Xu}, \mathrm{G} \mathrm{L} \mathrm{Ji} \mathrm{[1],} \mathrm{and} \mathrm{the} \mathrm{toxicity} \mathrm{of} \mathrm{Al}$ compounds in solution CJ Asher [2]. It was noted that the significant decrease in the atmospheric emission of acidic reagents reached in some economically developed countries does not always result in an expected increase in the soil $\mathrm{pH}$ and a decrease in the sulfate concentration in the soil solution [3]. This is related to the complexity and inter relation of diverse reactions with the participation of sulfates in the "soil solid phase-soil solution" system, which is difficult to adequately describe by mathematical models. It is well recognized that the adsorption of sulphate by soils and soil materials occurs by replacement of $\mathrm{M}-\mathrm{OH}$ or $\mathrm{M}-\mathrm{OH}$ groups Parfitt [4]. Sulphur is brought into the soils of forest ecosystems from three major sources: weathered minerals, decomposed organic matter, and atmospheric precipitation. Metal sulfides (predominantly iron sulfides) and gypsum are the main carriers of Sulphur [5-12].

The content of sulphur in the upper horizons of nonsaline soils varies from $0.01-0.02$ to $0.2-0.4 \%$. The lowest concentrations and reserves of sulphur are found in low-humus sandy and loamy sandy soils. The highest sulphur content is typical for peat soils and peats. In the upper humus horizons, the organic compounds of sulfur make up to $70-80 \%$ of the total sulphur pool. Sulphur occurs in soils in both organic and inorganic forms. Their ratio depends on the soil type and the occurrence depth of the horizon under study. Elementary sulphur is also found in soils, especially in the areas of recent volcanic activity. Sulphur is accumulated in soils predominantly as adsorbed sulphates in soil solutions, living plant tissues, and soil organic matter. Equilibrium is established in this system under natural conditions; it is shifted under the effect of acid precipitation, and the new equilibrium takes different time periods in different soils to become established [13-22].

\section{Research Methodology}

\section{Materials and reagents}

\section{Materials:}

a) DR/2000, Direct reading spectrophotometer.

b) Filter paper.

c) Spatula and Stirrer.

d) Beakers.

e) Conical flask.

f) $\mathrm{pH}$ meter.

g) Reagent Bottles.

h) Funnels.

i) Beam Balance.

\section{Chemicals and reagents:}

a) Sulfate (SO2- ) $5 \mathrm{mM}$ concentration.

b) Hydrochloric Acid ( $\mathrm{HCl}$ ).

c) Sodium Hydroxide $(\mathrm{NaOH})$.

d) Distilled Water. 
e) Raw Clay.

f) Modified Kaolin with surfactant HDTMA-Br (Picture 1).

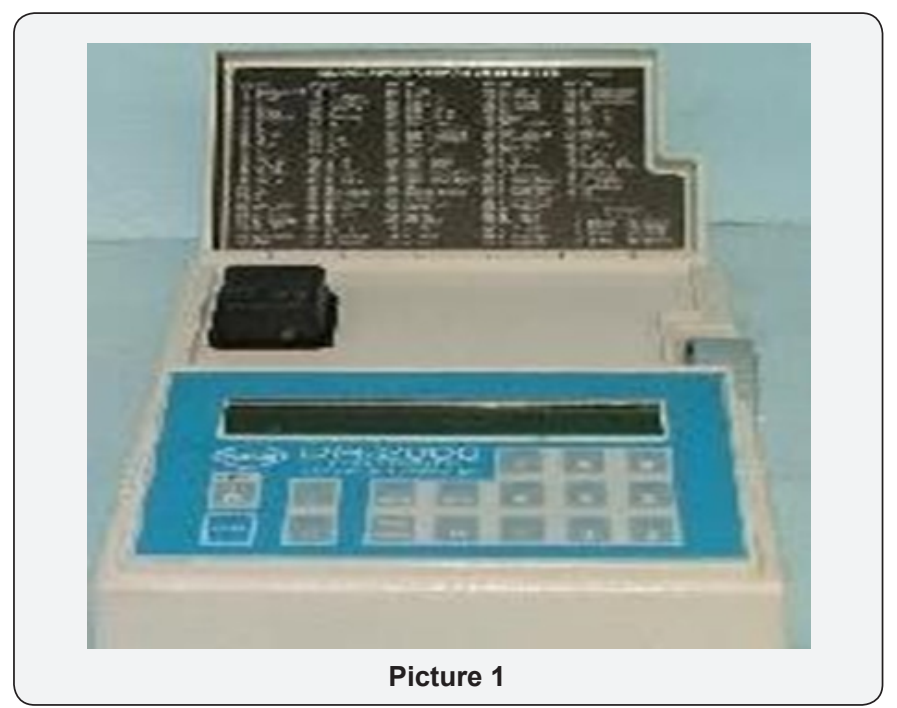

All chemicals were obtained from Soil and Science Department Laboratory. Distilled water obtained from Maiduguri Water Treatment Plant. Used for the preparation of all samples and standard solutions [22-30].

\section{Experimental procedure preparation of organoclay}

The organoclay sample was prepared from raw kaolin by the addition of HDTMA-Br, (hexadecyltrimetylammonium bromide) solution. 69.2455g of HDTMA-Br was weighed with a beam balance from the department of Soil and Science Laboratory University of Maiduguri and dissolved in $250 \mathrm{ml}$ of distilled water to prepare solutions of HDTMA-Br $100 \%$ CEC of Kaolin clay. $100 \mathrm{~g}$ of clay was also weighed and dissolved in HDTMA$\mathrm{Br}$ solutions and transferred into a batch reactor. The aqueous mixtures were then shaken laterally at room temperature for 24 hours. After centrifugation, the organoclay sample were filtered and washed several times with distilled water, dried and stored for use in the experiment [31-38].

\section{Sulfate-organoclay interaction}

Organoclay sample prepared from kaolin clay was treated with solutions of known initial concentrations of $5 \mathrm{mM}$ and continuously stirred for about 15-30 minutes. The amount of clay used for this experiment was approximately $100 \mathrm{~g}$ for each. Samples were taken within intervals of 1 hour for each solution for the sulfate sorption. Final sulfate concentrations in the supernatant solutions were determined by D.R. Spectrophotometer. The effect of $\mathrm{pH}$ on sulfate sorption was also investigated by adjusting the $\mathrm{pH}$ to 7.5 using $\mathrm{NaOH}$ and $\mathrm{HCl}$. After 15-30 minutes of stirring, the sulfate concentrations of the solutions were determined by D.R Spectrophotometer.

\section{Preparation of aqueous sulfate solution}

Stock Sulfate Solution, 5mM: Aqueous solution of hexavalent sulfur was prepared by dissolving appropriate grams of sulfate
(SO42-) in distilled water and completed to $1000 \mathrm{~mL}$ stock solution. $25 \mathrm{~mL}$ of stock solution was dissolved in $500 \mathrm{~mL}$ distilled water for a concentration of $5 \mathrm{~mL}$. Desired $\mathrm{pH}$ of solution (7.4) was adjusted with $\mathrm{NaOH}$ and $\mathrm{HCl}$ [39-44].

\section{Sulfate determination}

DR 2000 Model adsorption Spectrophotometer was used for sulfur measurements.

\section{Using the Dr 2000 spectrophometer to measure sulfate ion}

a) The stored programme number for sulfate ion was entered (i.e 90).

b) The wavelength was rotated to $540 \mathrm{~nm}$.

c) 'READ/ENTER' was pressed and $\mathrm{mg} / \mathrm{l} \mathrm{Cr} 6+$ was displayed.

d) Then the sample cell was filled with $25 \mathrm{ml}$ of sample.

e) Content of 1 chromaver 3 sulfate powder pillow was added to the cell (the prepared sample) and was swirled to mix.

f) The shift timer was pressed when the time beeped, and a 5 minute reaction period started.

g) Another sample cell was filled with $25 \mathrm{ml}$ of sample (the blank).

h) When the timer beeped, it showed mg/L of sulfur and the blank was placed into the cell holder and the light shield was closed.

i) Zero was pressed, and the display showed wait, and then $0.0 \mathrm{mg} / \mathrm{l}$ sulfur.

j) The stopper was removed, and the prepared sample was placed into the cell holds. The light shield was then closed.

k) Read/enter was pressed, and the display showed wait, and then the result in $\mathrm{mg} / \mathrm{l}$ of sulfur was displayed.

\section{Result and Discussion}

\section{Result}

Table 1: Adsorption of Sulphate ion at $\mathrm{pH} 7.5$ for Modified and Unmodified Clay.

\begin{tabular}{|c|c|c|}
\hline Time (hr) & \multicolumn{2}{|c|}{ Concentration of Sulphate ion left in solution(mg/L) } \\
\hline & Modified Clay & Unmodified Clay \\
\hline 0 & 580 & \\
\hline 0.5 & 560.5 & 577.01 \\
\hline 1 & 532.8 & 572.45 \\
\hline 2 & 490.12 & 568.95 \\
\hline 3 & 465.05 & 568.55 \\
\hline 4 & 461.25 & 567.12 \\
\hline 5 & 461.10 & 567.01 \\
\hline 6 & 461 & 567 \\
\hline
\end{tabular}


Table 1: Adsorption of Sulphate ion at pH 7.5 for Modified and Unmodified Clay.

Table 2: Amount of Sulphate ion adsorbed (mg/L) at $\mathrm{pH} 7.5$. Table 2: Amount of Sulphate ion adsorbed (mg/L) at $\mathrm{pH} 7.5$.

\begin{tabular}{|c|c|c|}
\hline Time (hr) & \multicolumn{2}{|c|}{ Amount of Sulphate ion adsorbed (mg/L) } \\
\hline & Modified Clay & Unmodified Clay \\
\hline 0 & 0 & 0 \\
\hline 0.5 & 19.5 & 2.99 \\
\hline 1 & 47.2 & 7.55 \\
\hline 2 & 89.88 & 11.05 \\
\hline 3 & 114.95 & 11.45 \\
\hline 4 & 118.75 & 12.88 \\
\hline 5 & 118.9 & 12.99 \\
\hline 6 & 119.0 & 13.00 \\
\hline
\end{tabular}

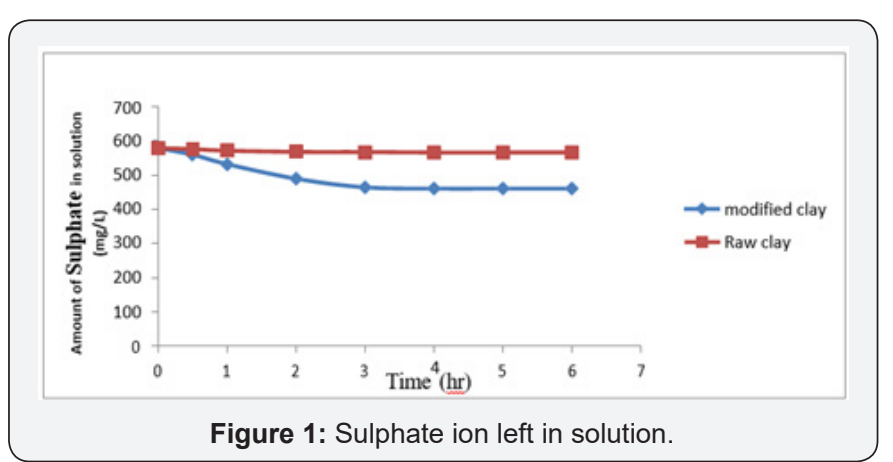

Figure 1: Sulphate ion left in solution.

Figure 2: Sulphate ion adsorbed from solution.

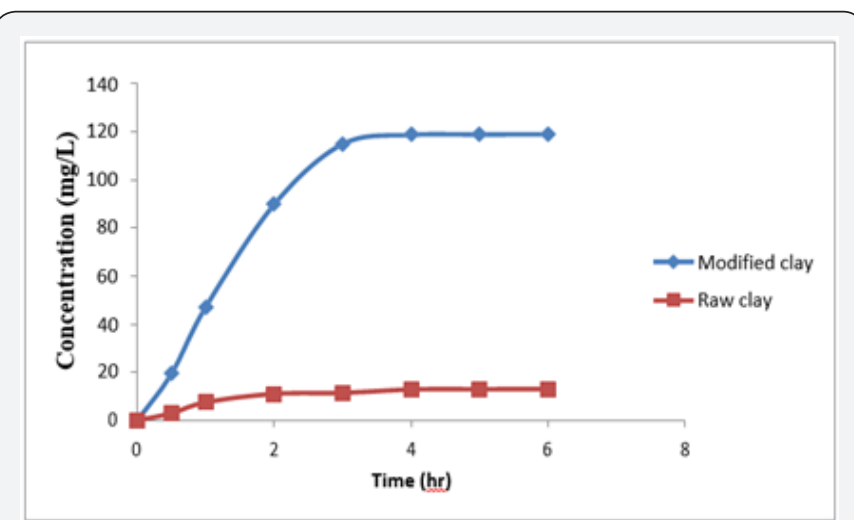

Figure 2: Sulphate ion adsorbed from solution.

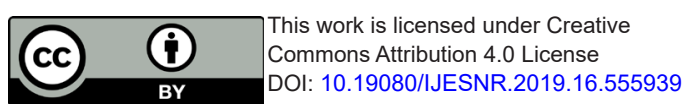

\section{Conclusion}

The data obtained from the study on the adsorption of sulphate onto organoclay provided a fundamental information in terms of optimum concentration for maximum removal of sulphate from solution. The maximum sulphate removal was found to be $119 \mathrm{mg} / \mathrm{L}$ and $13 \mathrm{mg} / \mathrm{L}$ for modified and unmodified clay at a $\mathrm{pH}$ of $7.5 \mathrm{in} 3 \mathrm{hrs}$. with $580 \mathrm{mg} / \mathrm{L}$ of initial concentration. The study also indicated that modified clay can be used to develop high capacity adsorbent material for the removal and recovery of heavy metal ions from the dilute industrial waste water streams. It can be concluded that the modified clay is a suitable adsorbent for the removal of sulphate from contaminated water in terms of natural and valuable alternatives for commercial sorbents. Further studies should be carried out in order to know the exact amount of the adsorbent and the exact $\mathrm{pH}$ solution that should be used for the effective removal of contaminants from a specific environment concerned.

\section{References}

1. Gleick PH (1993) Water in Crisis. Oxford University Press, New York, USA.

2. Kundzewicz ZW (1997) Water resources for sustainable development. Hydrological Sciences Journal-des Sciences Hydrologic 42(4): 467480.

3. Vorosmarty CJ, Green P, Salisbury J, Lammers RB (2000) Global water resources: vulnerability from climate change and population growth. Science 238: 284-288.

4. Mulugeta S, Yohannes F, Rashid SM (2006) Soil erosion assessment of lake Alemaya catchment, Ethiopia. Land Degrade Develop 17(3): 333341.

5. Foster GR, Lane LJ (1981) Simulation of erosion and sediment yield from field-sized areas. In Tropical agricultural hydrology, ed R Lal and EW Russell. Chichester, Wiley pp. 375-394.

6. CSA (2005) Central Statistical Authority of Ethiopian, Addis Ababa, Ethiopia.

7. Cho VT, Maidment, LW Mays (1988) Applied Hydrology, McGraw Hill, Inc.

8. OESPO (1999) Agricultural sector study: Soil resources in Oromiya. Draft, final Report, Oromiya Economic Study Project Office.

9. Nill D, Schwertmann U, Sabel Koschella U, Bernard M, Breuer J (1996) Soil Erosion by Water in Africa Principles, Prediction and Protection. Rossdorf, Germany TZ Verlagsgesellschaft.

10. (2004) SCUK/DPP. Final Report of Terminal Evaluation of Emergency Nutrition Intervention Program in Shashego and Hulbareg woredas of the SNNPR, Ethiopia.

\begin{tabular}{l} 
Your next submission with Juniper Publishers \\
will reach you the below assets \\
- Quality Editorial service \\
- Swift Peer Review \\
- Reprints availability \\
- E-prints Service \\
- Manuscript Podcast for convenient understanding \\
- Global attainment for your research \\
- Manuscript accessibility in different formats \\
( Pdf, E-pub, Full Text, Audio) \\
- Unceasing customer service \\
Track the below URL for one-step submission \\
https://juniperpublishers.com/online-submission.php \\
\hline
\end{tabular}

